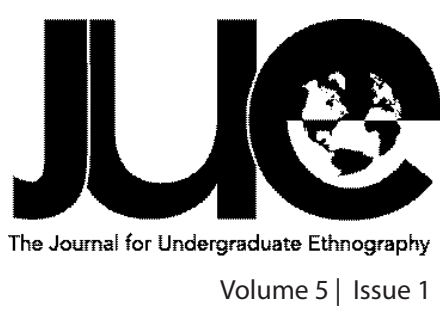

\title{
Constructing Home and Community in Halifax Housing Cooperatives
}

\author{
Shannon Turner and Elyssa Canning \\ Dalhousie University, Shannon.Turner@dal.ca \& el595077@dal.ca
}

\begin{abstract}
he subject of housing is a complex and multifaceted one in contemporary Canadian society, and urban areas in particular. Cooperative housing addresses a multitude of housing-related issues and provides an alternative model of affordable and sustainable housing solutions for a diverse cross-section of citizens. Housing cooperatives (co-ops) are a specific response to a variety of urban housing issues, from planning and sustainability, to housing scarcity and affordability. They also address fundamental social issues, from social isolation and marginalization to community building and creation of identity. This paper uses an ethnographic approach to explore how the structure of housing cooperatives and their ideals of cooperation and community translate meaningfully into a sense of place and identity for their members. It looks at how the social production of space relates to the social construction of space within cooperatives, how cooperatives address issues of affordable housing, and how coops deal with social distance and community building within urban environments. The findings of this research demonstrate the dynamic ways in which housing cooperatives meet the social and economic needs of diverse individuals within an urban social and economic landscape, establishing sense of home and community for their members, and offering an affordable and sustainable model of housing.
\end{abstract}




\section{INTRODUCTION- INVESTIGATING THE VALUE OF COOPERATIVE HOUSING}

"We behave as we are housed" - Alexander Laidlaw, in Housing You Can Afford

The subject of housing encompasses both social and economic concerns, and involves individual and societal needs, institutional structure and policies, and dynamics of power and inequality. Housing cooperatives are socially relevant because housing is a complex issue faced by contemporary societies, and urban areas in particular. Cooperative housing makes an intriguing focus of research because it addresses a multitude of housing-related issues and provides an alternative model of affordable and sustainable housing solutions for a diverse crosssection of citizens. The collective and self-sustained approach of cooperative housing holds the potential for empowerment of its members and for the creation of community within urban environments. Because cooperative housing provides shelter for many citizens of Halifax, we sought to gain insight into the structure of the cooperatives and operation by their members, as well as what sorts of value and meaning members derive from living in the cooperative. In doing so, we hoped to answer the question: How do the social production and social construction of space create a sense of place and community for co-op members?

Cooperative housing is a scientifically relevant topic to explore because it encompasses numerous social and structural factors that are specific to cities. Co-ops are a specific response to a variety of urban housing issues, from planning and sustainability, to housing scarcity and affordability. They also address fundamental social issues, from social isolation and marginalization to community building and creation of identity. In order to better frame our research, we set out to investigate the literature and previous research on the topic of cooperative housing, as well as to identify and define the key concepts and principles that we were working with, and the issues that relate to housing and urban living in a more general sense. We wanted to look at how the social production of space relates to the social construction of space within cooperatives, how cooperatives address issues of affordable housing, and how co-ops deal with social distance and community building within urban environments.

\section{HISTORY OF HOUSING COOPERATIVES IN HALIFAX}

The Cooperative Housing Federation of Nova Scotia was founded in 1981 as an umbrella organization overseeing housing co-ops across the province (Housing Cooperatives 1985, 1). The collective mission was to provide co-op members with secure, affordable, and decent housing (Housing Cooperatives $1985,3)$. Cooperative housing emerged in Halifax as a response to a housing crisis. Indeed, a 1981 census indicated that on the Halifax peninsula alone, at least $26 \%$ of households were spending over $30 \%$ of their income on shelter (Housing Cooperatives 1985, p. 8). Moderately priced housing was fast disappearing due to gentrification and condo-conversions, and only $11 \%$ of renters in Halifax could afford to purchase a house. As well, with a vacancy rate of only $4 \%$, it was not unusual for renters to see rent increases of $50 \%$ or more (Housing Cooperatives 1985, 18). Gentrification affects the North End in particular, meaning that processes of "urban renewal" have led to residents in a once primarily working class and Black neighborhood to be pushed out as middle-class people move in and rents increase (Baker 2014, 8). Initially, there were approximately 35 housing co-ops operating in Halifax, with 587 units providing homes for low-to-moderate income families. Currently, there are 48 co-ops in operation in the city, with 1165 units between them.

\section{SOCIAL PRODUCTION AND SOCIAL CONSTRUCTION OF SPACE}

In order to better appreciate what housing means to people, it is useful to understand how space is both socially produced and constructed. As defined by Setha Low (1996), the social production of space deals with the material structures and processes that produce space, whether the physical buildings themselves or the economic or planning policies that form them (861). The social construction of space refers to the ways in which people transform space and render it meaningful through their symbolic experiences and their use and perception of the space (Low 1996, 862). With this understanding, we demonstrate how the structure of housing cooperatives contributes to the value of members' experiences of living in a co-op. Low (1996) also refers to Foucault's examination of space as a form of social control, and Bourdieu's theories of how social structures are reproduced through the lived experiences of space (862-863). In this context, we can reflect on how cooperatives may constitute resistance to 
dominant power structures through the claiming or reclaiming of space, thereby constructing a particularly significant sense of meaning and identity for cooperative members.

\section{AFFORDABLE HOUSING AND CAPITALIST MARKETS}

Low's article addresses the ways in which claims to urban space are contested through various social and economic processes. Cooper and Rodman (1992) articulate this idea in an urban housing context through their discussion of exchange values and use values, which often play out in a conflict between market agents and residents seeking a quality of life (7). They argue that the commodification of housing and urban space has resulted in policies and decisions about urban land use that place an emphasis on exchange values, rather than on use values, which include such things as shelter, privacy, identity, and community (Cooper \& Rodman 1992, 7). Laidlaw (1977) asserts that private landownership and profiteering from land has meant that housing is controlled by producers such as developers and their allies, leaving the citizen consumer with little say or control (23). The capitalist ideology within North American society promotes personal autonomy, including independent homeownership, but economic power structures and increasing urbanization mean that this is not attainable for a growing majority of people. Additionally, housing shortages, race and class prejudice, and gentrification contribute to considerable gaps in the rental market and, as Laidlaw (1977) argues, "whatever form housing may take, there is a large and growing proportion of Canadians who are left without when the market economy is allowed to function as it will" (202).

Laidlaw (1977), in his study of Canadian housing cooperatives, argues that cooperatives address the inadequacies of the market housing system by providing a non-equity model of housing wherein people are able to utilize their collective power to address their own housing needs (21). While cooperative housing still entails private ownership, the advantage of this type of housing lies not in its resale value, but in its continued use by members (Laidlaw 1977, 105) and thus it is not subject to the inflationary forces of the equity housing market. Because housing cooperatives operate on a break-even basis, charging only as much rent as is necessary for the maintenance and operation of their buildings, they essentially act as an informal system of rent control. In this way, they are able to provide stable, afford- able housing for their residents, with a minimum of bureaucratic oversight (Laidlaw 1977, 121).

\section{SOCIAL DISTANCE AND COMMUNITY-BUILDING IN URBAN ENVIRONMENTS}

As demonstrated in the previous section, institutional control of housing by markets and governments and the forces of urbanization, such as gentrification, can contribute to the marginalization of many city-dwellers. The discussion of exchange vs. use values also highlights how the functional and affective aspects of housing are often inextricably linked (Cooper \& Rodman 1992, 7). The issue of how emotional needs are met by housing takes on increasing significance in light of Fran Tonkiss's (2005) work, which discusses how urbanism tends to produce a fragmentation of traditional social relations and support networks (13-14). Tonkiss examines how urban sociality moves away from the Gemeinschaft model based on mutual ties of interdependence toward the Gesellschaft model of more formal, impersonal interactions and increasing social distance (12). While pointing to the alienating factors of urban life, at the same time, Tonkiss emphasizes that the social and spatial isolation of urban environments have the potential to draw people together in the formation of new types of solidarity and community (14) and says that community can be viewed as being both defensive and assertive (16). In this way housing cooperatives can be seen as defensive in the practical sense of protecting their members against housing scarcity and economic disadvantage, as well as well as being an assertive gesture in the affective sense of providing support and identity for their members.

As Tonkiss states, "community can provide a vehicle for mobilization, opposition, for a positioning and a claim to voice" and housing cooperatives can certainly be understood in this context (25). Equally, Rae Bridgman's (2006) work with homeless people in Toronto explores how disenfranchised and marginalized individuals can achieve empowerment and build community when given the opportunity to act on their own behalf (188). Laidlaw (1977) explains that the foundational structure of co-ops, which is based on collective ownership and democratic control (48), can foster the creation of community and provide the means for members to address both group and individual needs beyond those of basic shelter (89). Cooper and Rodman's (1992) work elaborates on this by describing how co-ops enable members to 
control use values by taking the management of housing in their own hands, empowering citizens who have previously had the circumstances of their housing controlled by others (10), which allows them to meet a diversity of housing needs and improve their quality of life (269). Cooper and Rodman assert that housing cooperatives are not just buildings, but small societies with the goal of community at their heart (79). This again relates to Tonkiss' $(2005,12)$ discussion of Gemeinschaft and urban community, as co-op members can be understood to be part of an informal social economy of mutual reliance and must therefore navigate the tensions between individual and collective life. In this way, a housing co-op can be seen as a small but complex social world, or as Laidlaw $(1997,185)$ describes it, "a village within a city".

\section{WHAT IS COMMUNITY?}

In light of this discussion of creating community, it is important to attempt to define what community actually means. As Laidlaw (1977) discusses, traditional ideas of community deal with the relationship of individuals to a larger group living within close proximity, the ways in which bonds are produced through social and cultural activities, and how formal ties of interdependence create a more rational order of life (184-185). More recently, Tonkiss (2005) identifies three types of community that often overlap, each of which can be related to cooperative housing: the community of locality, which applies based on the fact that all the members are living in spatial proximity to each other; the social model of community, which applies because they are not only living as neighbors but also operating within the institutional framework of the cooperative; and the affective community, which applies because cooperative living can contribute to a shared identity and set of values for many of its members, who also belong to a broader network of cooperatives operating both within the city and nationally (15). As Tonkiss notes, the social and spatial aspects of community are often merged, in what she calls "the process of making and holding space" in response to social distance (17). However, in their role as little urban villages, housing cooperatives manage to avoid the spatial segregation and 'ghettoization' that often characterizes public housing projects and leads to the exacerbation of social problems. Housing cooperatives tend to be small in scale, geographically dispersed throughout city neighborhoods, and rather than resulting in a closing off and separation from the broader society, they can actually work to articulate a removal of boundaries.

Cooper and Rodman (1992, 89-90) explore the concept of community within a housing co-op through three definitions framed by the co-op members themselves, which intersect with yet are distinct from Tonkiss's three models of community. The first is the traditional view, in which ties are based on shared values and interests, and mutual concern and interaction. The second is the organizational form, wherein the structure and shared sense of responsibility within the co-op encourages social bonds and brings about change in individuals (Cooper \& Rodman 1992, 91-92). The third is what they term the "new age" view, which emphasizes communication, commitment to relationships and sharing of conditions, and requires the overcoming of differences and the transcendence of structure and self (93-94). While each of these understandings of community relations within co-ops entails a different approach, Cooper and Rodman's examination highlights the importance each definition places on democratic and humanistic values and the willingness of individuals to participate in the processes of the co-op (86-87). In this way, we can see how members' experiences of community within housing co-ops are influenced by the values they hold and their personal roles within the co-op structure.

\section{METHODS \\ Objectives}

We proposed to look at how cooperatives operate and how social relationships are negotiated within the cooperative. Our intention was to see how cooperative members evaluate the experience of living in a co-op, both on an interpersonal and intrapersonal level. We sought to understand the role of individual members within the co-op, how the co-op is set up and managed by its members, and how social dynamics play out within them. In addition, we also looked at the learning process and skills gained through co-op living, as well as how relationships and processes within the co-op were tied to certain ideologies and identities for members. In doing so, we hoped to determine how the structure and operation of the co-op builds and reinforces relationships and meanings and create a sense of place for its members. We anticipated that despite occasional conflict between members, overall the cooperative serves each member 
better than individual housing. Furthermore, we expected to find that cooperative housing provides members with a sense of community, belonging, and support that may be unavailable in an otherwise potentially isolating urban community, and creates both physical and social proximity.

Setting out

Our initial steps into understanding housing cooperatives were to conduct reviews of relevant social sciences literature on the subject of cooperative housing. In particular, we looked at the history of cooperative housing in Canada and specifically in Halifax, as well as examining contemporary ethnographies of specific housing cooperatives. We also looked at quantitative data concerning income and poverty levels, and rental and housing markets within the Halifax Peninsula, in order to gain some contextual reference for understanding the existing social conditions and issues related to housing in the Halifax area. To answer our research question and to get a scope of how members feel about their own personal experiences of the cooperatives we used several ethnographic methods, namely, in-depth semi-structured interviews, observation of participants' living environments, and construction of housing timelines for each participant. Our interview questions aimed to probe how people felt living in the cooperative, so most of them focused on the interviewees' relationships with other members and what they got out of the cooperative living experience in general. We also collected information such as previous living situations (and how they compare with cooperative housing), how the cooperatives are run and their personal role within the cooperative. At

\begin{tabular}{|c|c|c|c|c|c|}
\hline Name & $\begin{array}{l}\text { Time in } \\
\text { co-op }\end{array}$ & Cohabitation & Role in co-op & $\begin{array}{l}\text { Is co-op a long- } \\
\text { term solution }\end{array}$ & $\begin{array}{l}\text { Previous } \\
\text { housing }\end{array}$ \\
\hline Jordan & 2.5 years & $\begin{array}{l}2 \text { roommates, } 1 \text { is } \\
\text { co-op member }\end{array}$ & $\begin{array}{l}\text { Former chair of } \\
\text { maintenance } \\
\text { committee }\end{array}$ & Yes, probably & $\begin{array}{l}\text { Renting: roommates/ } \\
\text { alone } \\
\text { Built house with } \\
\text { partner }\end{array}$ \\
\hline Lizette & 9-10 years & $\begin{array}{l}\text { Used to have } \\
\text { roommates but } \\
\text { alone now }\end{array}$ & $\begin{array}{l}\text { Former chair of } \\
\text { board }\end{array}$ & $\begin{array}{l}\text { Unsure } \\
\text { Maybe buy a house? }\end{array}$ & $\begin{array}{l}\text { Renting: roommates/ } \\
\text { alone }\end{array}$ \\
\hline Morgan & 13 years & Her son, age 6 & $\begin{array}{l}\text { Former president } \\
\text { Has been on every } \\
\text { committee }\end{array}$ & $\begin{array}{l}\text { Yes } \\
\text { "I'll die in this } \\
\text { building" }\end{array}$ & $\begin{array}{l}\text { Renting: roommates/ } \\
\text { partner }\end{array}$ \\
\hline Carly & 3 months & Lives with partner & $\begin{array}{l}\text { On maintenance } \\
\text { committee }\end{array}$ & Yes, until I can own & $\begin{array}{l}\text { Renting: roommates/ } \\
\text { partner }\end{array}$ \\
\hline Paige & 1.5 years & Alone & $\begin{array}{l}\text { VP } \\
\text { On maintenance } \\
\text { committee }\end{array}$ & Yes, until I can own & $\begin{array}{l}\text { Renting: roommates/ } \\
\text { alone }\end{array}$ \\
\hline Julika & 11 months & Her son, age 4 & $\begin{array}{l}\text { Treasurer } \\
\text { On executive and } \\
\text { finance committees }\end{array}$ & Yes, until I can own & $\begin{array}{l}\text { Renting: roommates/ } \\
\text { alone } \\
\text { Living with family }\end{array}$ \\
\hline
\end{tabular}

Table 1: Research participants and key themes 
University accommodations

Apartment (shared)
Apartment (solo)

House (rented)
House (owned)

Co-op

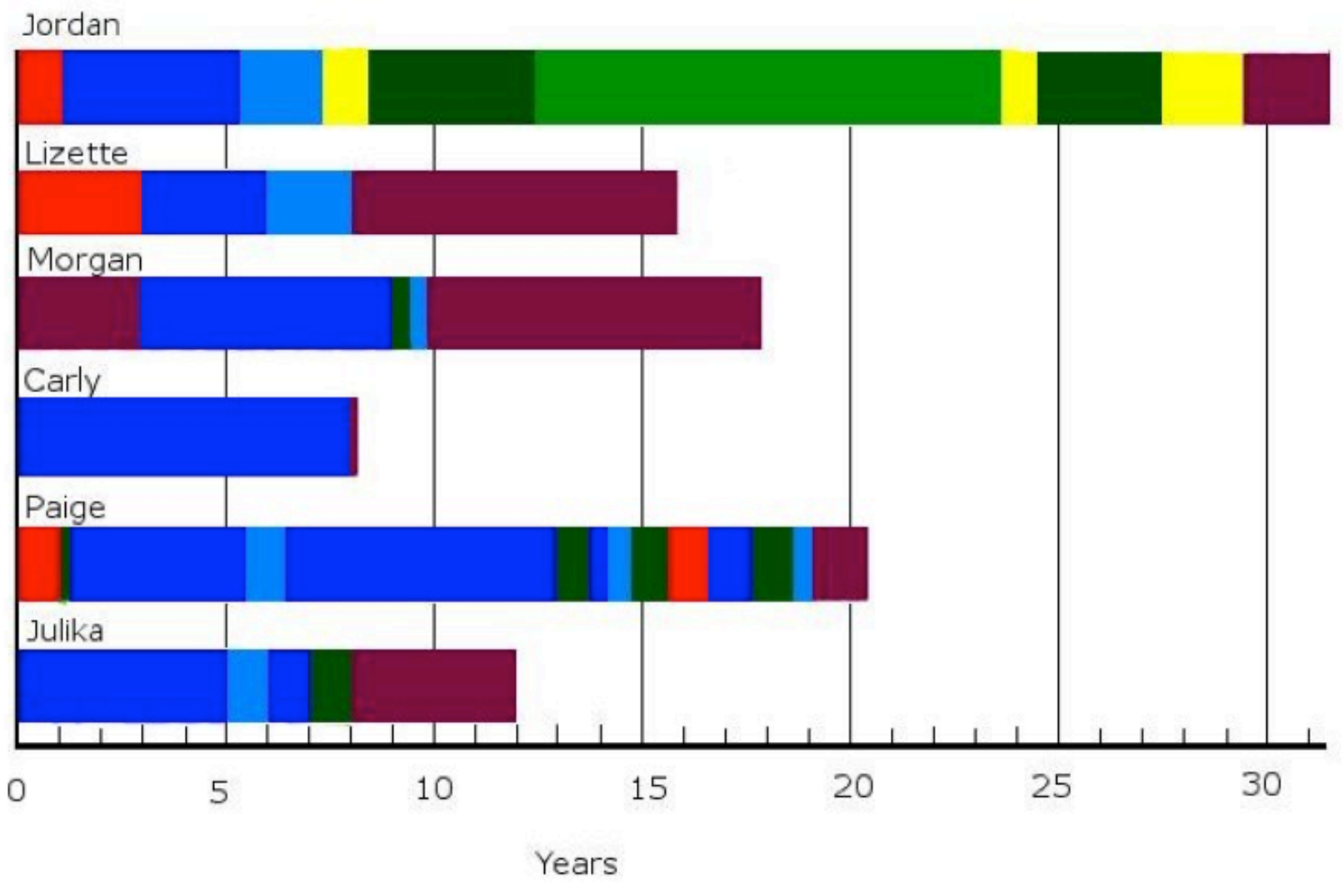

Figure 1:Timeline of Previous Housing

the end of each interview we drew up a timeline of participants' housing history. These housing timelines provided us with some good background information, made it easier to compare participants' histories and also brought their personal experiences into focus.

To find research participants, we decided to start with existing connections in the hopes of following the network in a sort of snowball effect. Shannon contacted a friend she knew to be living in a co-op who put us in touch with people living in her own co-op and others. In the end, we got interviews from three different cooperatives: Halifax Women's Housing Cooperative (three interviews), Longhouse Housing (two interviews), and Green Stem Housing Cooperative (one interview). We obtained this last contact coincidentally: Shannon was searching for a place 
to live and an acquaintance who was looking for a roommate contacted her. It turned out that the acquaintance was living in a co-op so we used the opportunity to get another interview. Five of our interviewees are female and one is male; all of them are single; two of them have children. All of their housing co-ops are located in the North End, a working-class Halifax neighborhood that is struggling with increasing forces of gentrification that have made it ever more difficult to find affordable housing. Research ethics

Throughout the interview process, we kept ethical considerations in mind. We made sure that we answered any questions our interviewees had about why we were asking them these questions and tried to clarify what it was we were setting out to do. We asked all of our interviewees to sign a consent form and asked them whether they preferred to remain anonymous. Although most of them seemed okay with having their names used, one of the interviewees expressed an interest in remaining anonymous. For this reason, and because using real names seemed unnecessary, we have given all of our interviewees pseudonyms, which we use throughout the rest of the paper. Analysis

After we conducted each interview, we listened to the audio recordings, wrote down the most important parts and plotted them on a table of participants, paying close attention to the emerging patterns (see Table 1). We also transcribed quotes from the interviews that stood out. We took the timelines and used a graphic design tool to put all of the timelines together to compare their housing experiences, again paying close attention to patterns that were emerging (Figure 1). Finally, we looked at how the information that we had gathered fit in with social science concepts we have covered and compared with some of the outside resources we looked at.

\section{FINDINGS}

\section{How the Cooperatives Function}

There are three different committees within each cooperative (Figure 2): a finance committee, a maintenance committee and a membership committee. Members take on all of the executive roles, which include a president, vice president, secretary and treasurer. There is one meeting a month that all the members attend, as well as meetings once a month for the other committees. There are various levels of commitment from members as well as various levels of organization within different co-ops. Empowerment

Cooperative living provides members with a feeling of empowerment. An important aspect of cooperative living is that, as all members are required to take some responsibility for running the cooperative, it creates a feeling of egalitarianism where all members are generally given the same amount of power. Even though some members may take on more 'important' roles at one time, all members are offered the opportunity to take on these leadership roles. Members often change roles and have the opportunity to explore new ones until they find one that suits them and provides them with a sense of personal authority. In Jordan's case, he went through a couple of roles before he found that maintenance suited him quite well and gave him the feeling that he was really contributing.

Cooperatives enable members to feel empowered within a capitalist housing market that is typically disempowering for many low-to-middle income people. The egalitarian structure of the co-op allows members to reclaim a sense of control over the circumstances of their housing. As Jordan says,

"When you're with a landlord, it's just a throw of the dice. Sure you can get a great landlord but you can get an asshole too. And if it's an asshole, they just automatically have more power than you. So if it's an asshole that's a problem. There can be an asshole in a co-op too, but they're an asshole that has the same amount of power as you."

This quote emphasizes the importance of cooperatives in creating an atmosphere where, while dealing with adversity, a resolution must be reached in the most equitable manner possible. No one person's wishes or opinions are considered more important than another's.

Through the cooperatives, women are empowered to take on non-traditional roles. Morgan says she's learned "a ton" about maintenance issues, as well as business management skills, through dealing with the many facets of running a co-op. Furthermore, all members are offered the opportunity to express their opinions and have their voices heard.

Cooperation and Conflict

As comes with the territory of working with others, conflict inevitably arises within the cooperatives. There are many individuals trying simultaneously to meet their own interests, while remaining productive and doing what is right and needed within 


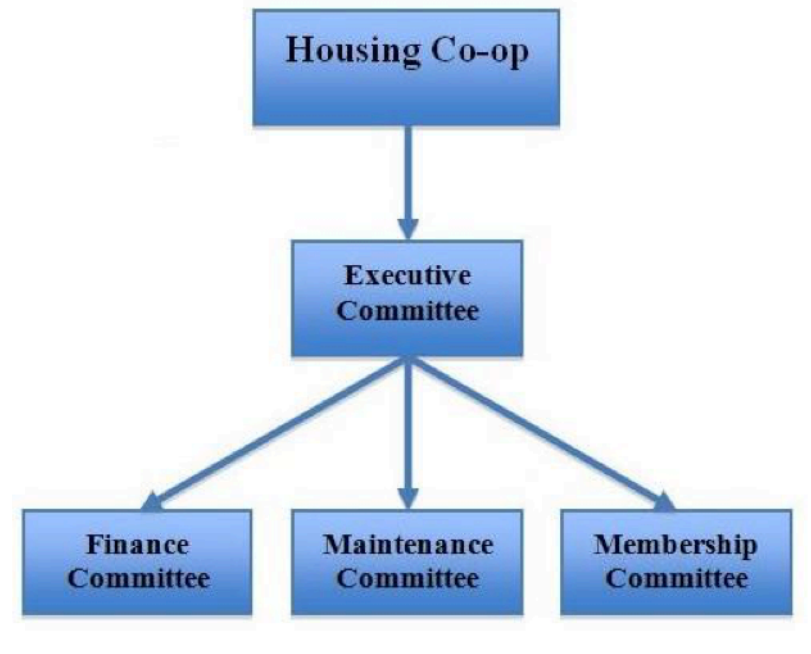

Figure 2: Organizational Structure of Housing Co-ops

the cooperative. Quite often this results in a conflict of interest between members that needs to be resolved. Moreover, productivity and group cohesion can be easily diminished by even one negative attitude. We had at least two interviewees express frustration at individual members of their cooperatives who did not work in the interest of the communities, leading to meetings that were prolonged and filled with negative energy. "It's been difficult and intense," Jordan told us. "The learning curve is huge...I feel like a lot of people go into co-ops for the low rent, and I think that's a really lousy reason to go into a co-op."

However, from this type of conflict arises an opportunity for growth which can be either embraced or ignored. Morgan emphasized the importance of resolution, stating that if conflicts were unresolved conflict would linger, creating an unpleasant atmosphere, but if resolved they could lead to group cohesion and could actually bring the members closer to each other. Lizette brought up an important point of cooperatives, which is that, unlike many other types of urban neighbors, co-op members interact on a daily basis whether they want to or not, which increases the importance of cooperation and mutuality. We noted that many of the co-ops have both shared common hallways and outdoor green space, and members frequently see and acknowledge each other, if only in passing, within these shared spaces. Morgan said, "I enjoy that I have frequent social interactions with people. My door is open, people walk in the hallways... just your typical neighbourly can-I-have-a-cup-of-sugar sort of thing down to our roof is falling off."

Skill-Building

Skill-building was an important factor of cooperative living for the members that we interviewed. Living and working with people is a skill that many found they improved upon while living in the cooperatives. Because members see each other on a regular basis, it is very important for them to maintain positive or at least friendly relationships with their neighbors, and to work through any conflict that might arise between them. By facing conflict, cooperative members learn about the dos and don'ts of group living and how to be productive while overcoming disagreements and strife.

Our interviewees found that membership through committees helped them to develop a skill set that they wouldn't have otherwise. One interviewee stated that the Cooperatives Housing Federation runs conferences that offer workshops such as 'How to Chair a Board Meeting' so that members gain the skills they need to run the cooperative effectively, and that the cooperative sponsors members to attend these conferences. Lizette further (indirectly) articulates the importance of taking on new roles in the co-op and of members challenging themselves. She states:

"I think it's a really good learning opportunity for people... learning about everything from maintaining a home to working on a committee or working with other people... so I think it's good for confidence. Over time learning 'oh, I can manage this, I can handle this, I can even chair a meeting... I can help run something".

This demonstrates the benefits that can be gained from living and working within a cooperative, especially for those who commit themselves to keep it running. Carly highlights another important aspect of cooperative living: preparing for potential homeownership and property management in the future. Carly was drawn to the cooperative because "I'd feel more like a grown-up if I was living in a co-op and it'd be a nice intermediary stage between renting and owning," and that she would "learn things that people who have homes learn". Overall, there are many skills that can be learned through participation in cooperative living, which can be applied to this particular housing situation or to life in general, and can be utilized in the future. 
Sense of Place, Pride and Ownership

Members put down roots inside the cooperatives. Our interviewees felt a strong sense of belonging in the co-ops and saw them as an integral part of their identity. This is likely heavily influenced by and related to the fact that they put a lot of time and effort into its maintenance. Many of the units we visited had a DIY aesthetic, and members noted things in their apartments that they had repaired or improved themselves, indicating a sense of place and pride in their self-determined living space. Often salvaged materials were used for low cost improvements, giving each unit a distinctive look, and the creative choices of each resident also gave each unit a vibe that was warm and personal. Lizette told us, "You do get to make choices about your unit. I get to paint it whenever I want, whatever color I want". When we were conducting our fieldwork, Paige pointed out the paint color she had chosen when she moved in, and Jordan showed us around and explained the various minor renovations he had made in his unit to better suit his lifestyle, such as built-in storage for his tools and other creative supplies. Co-op members we spoke to seemed to particularly appreciate being able to feel personally invested in their space, as well as feeling empowered to make necessary repairs and renovations.

Particularly fascinating is the way in which cooperatives in Canada started off as subsidized housing, but members began to see themselves as "autonomous self-help communities democratically controlled by members and concerned for the welfare of others" (Cole, 2008, p. 3). Members invest themselves in many aspects of the cooperatives: the physical space, the people and the ideal - which in turn results in a strong sense of attachment. Jordan said, "I want to put hours in doing stuff that otherwise we wouldn't be able to do." Bridgman $(2006,29)$ states that, "placemaking is less a blueprint then a process in need of continued renewal", and we can see the constant renewal of the place-making process in the members' continued personal investment in both the space and the community within.

Relationships and Support

Housing cooperatives offer members the opportunity to build relationships among themselves as well as form a network of support. For the most part, our interviewees had very positive responses when asked about their relationships with other co-op members, claiming them to be significantly stronger than those found in a typical renting situation. A couple of our interviewees added that relationships were better among those who play an active part in running the cooperatives. The fact that members work together on a regular basis both provides the incentive to build social ties and facilitates their daily interaction. Furthermore, meetings can be seen not only as a necessity in running the cooperative but also as a social activity that brings members together and provides the opportunity to catch up or get to know their neighbors.

Significantly, all of our interviewees asserted that they would be comfortable reaching out to the other co-op members in times of need. Although the question was met with various levels of enthusiasm, some emphasizing that they would not necessarily be the first ones they would go to, all of their answers were affirmative, which makes a clear distinction from other sorts of housing situations. There were also members who spoke of mutual initiatives or favors that happened in the cooperatives. Carly told us "There's a grapevine that one person planted and that other people make grape jelly out of and then other people make wine." Morgan expressed her appreciation for her neighbors who would take her child out for play-dates on occasion. This is an important example of the way in which the individual and group needs beyond shelter are met, initiated by other members. It is also an example of Gemeinschaft relations found within an urban environment. Interactions such as this go above and beyond the relations other housing situations normally provide, and are facilitated by the sense of mutual dependence and comradeship inside the cooperatives.

Participation and Commitment

Given the fact that cooperatives are sustained by their members, it is important to look at the participatory element of cooperative living. Overall, there are various levels of involvement from cooperative members. Naturally, those who responded to our call to answer questions about cooperative living were more enthusiastic members of the community. We were unable to make contact with non-participatory members who may be less motivated by the logistical elements of cooperatives and more motivated by low rent, which was made apparent in our results. All of our interviewees, holding the community and participatory elements dear to them, were naturally more inclined to talk to us. Consequently, our results are centered on an ideology of these elements rather than one of low rent. From the responses we got from members, we could ascertain that there 
was a community amongst the more participatory members of the cooperatives, stemming from the fact that there is so much cooperation involved in running and maintaining the cooperatives. These findings fall into line with those of Cooper and Rodman $(1992,270)$ who indicate "the most satisfied members had....a high level of involvement, and sense they could make things happen in co-op". We found that participation and cooperation formed an important part of identity and resulted in an increased sense of belonging for these members.

\section{Security of Tenure}

A key element in cooperative living is security of tenure. Every single member we interviewed spoke of it as one of the main benefits of cooperative living. Unlike in rental situations, members are not subject to the tendency of landlords to boot them out or raise rents without warning, and they know that when they leave it will almost always be of their own free will. This is a comfort for members, and it allows them to establish roots. Three of our interviewees expressed their gratitude for being able to grow a garden that they would be able to care for year after year, and we noted large and well-established gardens in the backyards of all of the co-ops we visited. At the Women's Co-op, Morgan showed us around the large shared green space and pointed out a few of the many improvements she had made in her years living there, including some perennial shrubs, and raised garden beds for herbs and vegetables. It became clear that members were not afraid to invest their time and energy into the cooperatives because they knew it would not go to waste.

Compared to Other Housing Options...

Overall, our interviewees were satisfied with their experience of cooperative housing as compared with their other housing options, and there are many factors that played into this. Jordan cited moral and ethical ideals as an important factor in his decision to live in a cooperative. He found that of the three models - renting, owning and cooperative living - the latter was the lesser evil, as it were: "I feel strongly that the cooperative model is the least screwed up of the three models". Particularly in contrast to renting situations, there is no need to deal with neglectful landlords. Lizette, on the other hand, found that her neighbors in the cooperative are a lot more respectful than in her previous renting situation. This likely stems from the fact that, because of their daily interaction with each other, members of the cooperative are more aware of those around them. It also nicely coin- cides with sources we found on possible motivation to move into a cooperative housing, with Andrews and Breslauer $(1976,27)$ claiming that one of the most common sources of dissatisfaction with previous housing is "exterior noise transmission" (32.4\%) and general dissatisfaction with their neighbors (28. 2\%).

After collecting information on participants' previous housing situations, we analyzed the data on this graph to discern any patterns that might appear, forming a housing timeline for each interviewee (Figure 1). What we found was that very few of our interviewees have lived in single family houses. A couple people lived in shared, rented houses for short periods of time and Jordan lived in a house that he had built for a significant amount of time, but none have ever purchased a house. Furthermore, although a few have lived in their own rented apartments for short periods of time, none had any lengthy periods of living solo. All of our interviewees, however, have lived for a long time (although not always in the same apartment or with the same people) in shared apartments. We think this plays a part in people's ability to integrate into cooperative situations, after having the experience of living with other people and gaining some (though not all) of the skills necessary.

Summary

Overall, the information we gathered generally fell in line with our hypotheses, and aligned well with previous research done by others. Cooperatives provide a sense of belonging and security for the members, essentially providing them with a "home" rather than just a "house". Furthermore, members learn valuable skills by facing the challenges that come with this sort of living situation. The one truly surprising result was the fact that virtually none of the interviewees cited "low rent" as an important factor in choosing cooperative housing, and many explicitly stated that they did not think this alone was an adequate reason to move into a cooperative. Of the two who cited low rent as their original reason for moving into the cooperative, they soon found that it was no longer the main benefit and that there were many more aspects of the cooperatives that they loved. This coincides with Laidlaw's $(1977,270)$ assertion that while the economic rewards can certainly be attractive to some members, the non-economic factors often outweigh them in importance.

Although we feel that our research provided us with some valuable information, we did run into a few limitations. One was that, due to time restrictions, we were not able to conduct 
as many interviews as we would have liked. Another was that, although we had originally planned to incorporate a considerable amount of participant observation into our research, we were unable to do this to the extent that we would have liked, again due to time restrictions. We conducted most of our interviews in members' homes and were able to make basic observations about their living spaces and some co-op member interactions, which contributed significant ethnographic insight. However, we did not get to do as much "hanging out" as we would have liked or sit in on meetings as we had planned. We also did not obtain interviews with less participative members of the cooperatives. Given the time we had and the amount of research we did, however, we are satisfied with our results.

\section{CONCLUSION}

We set out to understand how the structure of housing cooperatives and their ideals of cooperation and community translate meaningfully into a sense of place and identity for their members. We discovered that the structure of self-governance within co-ops creates a strong sense of empowerment, particularly for those who have previously experienced disempowerment in their life and housing circumstances. This sense of empowerment forms a strong sense of place and belonging for the members of the cooperative, fostering an important feeling of security and allowing for the building of relationships and community. It was also apparent that the democratic and egalitarian values found within co-ops make it possible for the expression and coexistence of differences. While it appeared inevitable that conflicts would arise between diverse personalities over the conception of differing needs and use values, these conflicts can be overcome through the ongoing commitment and participation of members. By building the skills and taking on the responsibility to meet their own housing needs, co-op members are able to not only build and sustain the long-term security of an affordable roof over their heads, but to create a vital quality of life and a sense of home, identity, and community within an urban environment.

In the co-op's expression of a democratically functioning, heterogeneous "village within a city," providing not just housing but community of various types and support for its residents, there appears to be enormous potential for addressing a variety of social concerns. In recognizing the economic instability and structural power inequalities in our contemporary society that lead to the marginalization of many groups and individuals, it becomes clear that values of collectivism and self-reliance in cooperatives create a powerful model for providing a means of both secure, affordable housing and community-building. The dynamic ways in which housing cooperatives meet the social and economic needs of diverse individuals are worthy of more thorough exploration than our research could encompass in the duration of this project. In the future, we would hope to undertake a more in-depth investigation of housing cooperatives, expanding our research to cover a broader range of co-ops and residents, in order to uncover a greater diversity of meaning and experience. For the moment, however, we feel that our research has at the very least revealed the significance of housing cooperatives within the urban social and economic landscape, and of their importance as both home and identity for their members. 


\section{REFERENCES}

Andrew, H. and Breslauer, H. 1976. Residential Movement: Choice of a Cooperative HousingProject. Toronto: University of Toronto.

Baker, Kelly. 2014. "We don't need another Africville": Historical Imaginings of Gentrification and Development in Halifax's North End. PhD thesis, University of Western Ontario - Electronic Thesis and Dissertation Repository. Paper 2391.

Bridgman, R. 2006. StreetCities: Rehousing the Homeless. Toronto: Broadview.

Cole, L. 2008. Under Construction: A History of Cooperative Housing in Canada. Ottawa: Borealis.

Cooper, M. and Rodman. 1992. M.C. New Neighbours: A Case Study of Cooperative Housing.Toronto: University of Toronto.

Laidlaw, A. 1977. Housing You Can Afford. Toronto: Green Tree.

Low, S.M. 1996. Spatializing culture: The social production and social construction of public space in Costa Rica. American Ethnologist, 23(4), 861-879.

The Halifax Housing Symposium. 1985. Housing Cooperatives: A logical solution to the Halifax housing crisis, June 11.

Tonkiss, F. 2005. 'Chapter 1. Community and Solitude: Social Relations in the City,' pp.8-29, Space, the City and Social Theory. Cambridge: Polity.

This work is licensed under a Creative Commons Attribution-

NonCommercial-

NoDerivs 3.0

Unported License. 